\title{
Investigation on Patients' Understanding and Concern about the Disease and Recovery Rate in Thyroidectomy Patients to Enhance Satisfaction of Hospitalization
}

\author{
Chang Myeon Song, Heejin Kim, Tack-Kyun Kwon, \\ Myung-Whun Sung, Kwang Hyun Kim and J. Hun Hah \\ Department of Otorhinolaryngology, Seoul National University College of Medicine, Seoul, Korea
}

갑상선 수술 환자의 입원 만족도를 높이기 위한

환자의 질병에 대한 이해도, 관심 사항 및 회복도 조사

송창면 · 김희진 · 권택균 · 성명훈 · 김광현 · 하정훈

서울대학교 의과대학 이비인후과학교실

Received April 28, 2010

Revised July 12,2010

Accepted July 16, 2010

Address for correspondence

J. Hun Hah, MD

Department of Otorhinolaryngology,

Seoul National University

College of Medicine,

101 Daehank-ro, Jongno-gu,

Seoul 110-744, Korea

Tel $+82-2-2072-0215$

Fax $+82-2-745-2387$

E-mail jhunhah@snu.ac.kr
Background and Objectives Diagnosis of thyroid disease requiring surgery and subsequent thyroidectomy may affect patients' emotion and quality of life. The purpose of this study is to evaluate the patients' understanding and concern about the disease and recovery rate after thyroidectomy, and therefore to enhance the satisfaction of hospitalization.

Subjects and Method Seventy-seven patients undergoing thyroidectomy in a tertiary hospital from April 2009 to October 2009 were enrolled. Questionnaires were filled out on the admission day, discharge day, and 2 weeks after operation. Questionnaires consisted questions regarding the understanding of the disease, details of concern, recovery rate after surgery, and satisfaction on hospitalization duration. Retrospective chart review was also performed.

Results Many patients (42.9\%) acquired their knowledge of thyroid cancer through the internet. The possibility of voice change was the major concern before surgery $(46.8 \%)$, whereas the major postoperative concern was adjuvant therapy $(37.7 \%)$. The patient group with higher understanding of the disease showed higher recovery rate than the others at the time of discharge (mean postdischarge surgical recovery $67.4 \%$ vs. $55.3 \%, p=0.01$ ). The patient group with lower understanding wanted longer hospitalization than the other group at discharge $(p<0.001)$.

Conclusion Patient education about the thyroid disease may reduce patients' anxiety and therefore may enhance subjective recovery rate and satisfaction of hospitalization.

Korean J Otorhinolaryngol-Head Neck Surg 2010;53:557-63

Key Words Thyroidectomy $\cdot$ Recovery $\cdot$ Satisfaction $\cdot$ Cognition
서 론

갑상선암은 모든 악성 종양 발생률의 $13.1 \%$ (한국, 2007 년), 암으로 인한 사망의 $0.2 \%$ 를 차지하는 종양으로 일생 동안 갑상선암이 발생할 확률은 약 $1 \%$ 이다. ${ }^{1,2)}$ 가장 흔한 고분화 갑상선암은 양호한 경과를 취하며, 90 95\%의 높
은 10 년 생존율을 보인다. ${ }^{3)}$ 고분화 갑상선암의 치료는 갑 상선 절제술과 방사선 요오드 치료, 갑상선 자극 호르몬을 억제하기 위한 갑상선 호르몬제 치료이다. 일반적으로 암의 일차적인 치료 결과는 생존 기간 분석을 통해 평가되었으 나, 최근 들어 암 환자 삶의 질에 치료와 치료 결과가 중요 한 요소로 알려졌다.,5) 갑상선암 치료에서 가장 중요한 수 
술을 위한 입원 기간과 관련하여, 입원 기간을 줄이기 위한 다양한 노력들은 많이 보고되었으나, 환자의 만족도 측면에 서 입원 기간에 대해 평가한 보고는 없다.

이에 본 연구는 갑상선 수술을 받기 위해 입원한 기간 중 환자의 만족도를 높이고자, 갑상선 수술을 받은 환자의 병 에 대한 이해도, 입원 전후의 근심 사항, 수술 후 회복 정도 등을 설문을 통해 분석하고자 하였다.

\section{대상 및 방법}

2009년 4월부터 2009년 10월까지 3차 의료기관의 이 비인후과에서 갑상선암을 의심하여 갑상선 엽절제술, 갑상 선 전절제술, 갑상선 전전제술과 중심 경부절제술(level VI dissection)을 받은 환자를 대상으로 설문 조사와 후향적 의무기록분석을 시행하였다. 중심 경부절제술보다 광범위 한 경부 절제술을 같이 시행 받은 환자, 설문조사를 거부하 는 환자, 3 개의 설문조사 중 한 개라도 작성하지 않은 환자 는 제외하였다. 후향적인 의무기록으로 환자의 나이, 성별, 학력, 실제 갑상선 절제술의 종류, 합병증을 조사하였다. 갑
상선 수술을 받은 환자 중 133 명의 환자가 설문지를 작성 하였으며, 그 중 3 개의 설문지를 모두 작성한 환자는 77 명 으로, 나머지 56 명은 연구에서 제외하였다. 환자의 나이는 평균 48.6세(최소 24세, 최고 79세) 였으며, 남녀 비는 2 : 5 (남자 22명, 여자 55명) 였다. 입원 기간은 평균 4.3일(최 소 3일, 최대 9일)이었다. 시행 받은 수술의 종류에 따라 갑상선 엽절제술은 14 명, 갑상선 전절제술은 30 명, 중심 경부절제술을 동반한 갑상선 전절제술은 33 명이었다. 조직 검사 결과 66 명은 갑상선 유두암, 2 명은 갑상선 여포암, 4 명은 여포성 선암(follicular adenoma), 2명은 선종성 갑상 선종(adenomatous goiter), 2명은 결정성 비대증(nodular hyperplasia), 1명은 미만성 여포성 비대증(diffuse follicular hyperplasia)이었다.

설문 조사는 입원 당일, 퇴원 당일, 그리고 수술 후 2주 째 외래에서 3회에 걸쳐 시행하였다. 입원일 설문조사 항목 은 갑상선암과 그에 대한 치료 과정에 대한 환자의 인지 정 도, 갑상선 질환에 대한 정보를 습득한 방법, 수술 전날 가 장 걱정되는 사항, 수술과 관련하여 가장 걱정되는 사항으 로 총 5 개의 항목이었다(Fig. 1). 퇴원 당일 설문 조사 항

\begin{tabular}{|c|c|}
\hline 설문지 질문 & 세부 항목 \\
\hline $\begin{array}{l}\text { '갑상선암’이라는 질병과 치료 과정 등에 관한 일반적인 } \\
\text { 사항에 대해 얼마나 알고 있다고 생각하십니까? } \\
\text { (한 항목만 } \mathrm{V} \text { 표 하시기 바랍니다) }\end{array}$ & $\begin{array}{l}\text { 충분히 잘 알고 있다(대략 } 75 \% \text { 이상 알고 있다) } \\
\text { 비교적 잘 알고 있다(대략 50-75\%) } \\
\text { 어느 정도는 알고 있다(대략 25-50\%) } \\
\text { 조금 알고 있다(대략 10-25\%) } \\
\text { 거의 모른다(대략 } 10 \% \text { 미만) } \\
\text { 암이라는 사실 외에는 전혀 모른다 } \\
\end{array}$ \\
\hline $\begin{array}{l}\text { 갑상선암에 대한 정보는 주로 어떻게 얻었습니까? } \\
\text { (한 항목만 } \vee \text { 표 하시기 바랍니다) }\end{array}$ & $\begin{array}{l}\text { 병원 진료 시간 } \\
\text { 병원 질병 안내 자료 } \\
\text { 인터넷 검색(검색 사이트를 기술하시오) } \\
\text { 인터넷 카페 (구체적으로) } \\
\text { 주변 사람들에게서 들음 } \\
\text { 기타(기술하시오) } \\
\text { 정보를 얻을 기회가 없었다. }\end{array}$ \\
\hline $\begin{array}{l}\text { 현재(수술 전) 가장 걱정하고 있는 부분은 어떤 것입니까? } \\
\text { (한 항목만 } \vee \text { 표 하시기 바랍니다) }\end{array}$ & $\begin{array}{l}\text { 암이라는 사실(암으로 진단 받았거나 진단 받을 가능성)에 대한 걱정 } \\
\text { 수술 및 수술 합병증에 대한 걱정 } \\
\text { 수술 후 추가적인 암치료 } \\
\text { 입원에 따른 사회 생활 차질 } \\
\text { 입원비 등 경제적인 부담 } \\
\text { 입원에 따른 가정 혹은 자녀 관련 걱정 } \\
\text { 기타(구체적 기술): } \\
\text { 특별히 걱정하는 것은 없다. }\end{array}$ \\
\hline $\begin{array}{l}\text { 수술과 관련하여 가장 걱정하고 있는 것은 무엇입니까? } \\
\text { (한 항목만 } \vee \text { 표 하시기 바랍니다) }\end{array}$ & $\begin{array}{l}\text { 전신 마취 부작용(마취에서 깨어나지 못할까 하는 두려움) } \\
\text { 수술 부위 통증 } \\
\text { 흥터 } \\
\text { 목소리 변화 등 합병증 } \\
\text { 수술 후 회복 지연(가사 혹은 직장으로의 복귀 지연) } \\
\text { 기타(구체적 기술) } \\
\text { 특별히 걱정하는 것은 없다. }\end{array}$ \\
\hline $\begin{array}{l}\text { 입원기간은 수술 후 의학적 소견에 따라 결정됩니다만, } \\
\text { 개인적으로 얼마나 오랫동안 입원하기를 희망하십니까? } \\
\text { (희망사항을 지켜드리지는 못함을 양해 바랍니다. } \\
\text { 한 항목만 } \vee \text { 표 하시기 바랍니다) }\end{array}$ & $\begin{array}{l}\text { 별로 생각해 보지 않아서 잘 모르겠다. } \\
\text { 전적으로 병원에서 알아서 잘 해 줄 것으로 생각한다. } \\
\text { 가능하면 빨리 퇴원하고 싶다. } \\
\text { 가능한 한 오랫동안 입원하고 싶다. }\end{array}$ \\
\hline
\end{tabular}

Fig. 1. The questionnaire inventory for preoperative evaluation. 
목은 수술 받은 당일 가장 힘들었던 점, 퇴원 날 가장 힘든 점, 퇴원 당일 당시의 입원 기간에 대한 의견, 적당하다고 생각하는 입원 기간과 그 이유였다(Fig. 2). 퇴원 후 외래 에서 설문 조사한 항목은 퇴원 당일 설문과 유사하였는데, 퇴원 후 가장 힘들었던 점, 퇴원한 이후 외래 진료를 받을 당시 입원 기간의 적정성에 대한 의견, 바람직하다고 생각 하는 입원 기간과 그 이유, 그리고 수술 전과 비교하여 환자
가 느끼는 전체적인 회복 정도의 비율을 퍼센트 $(\%)$ 로 표 기한 것이었다(Fig. 3). 퇴원 당일과 외래의 설문조사에서 는 수술 후 회복 척도(postdischarge surgical recovery scale, PSR scale)를 조사하였다(Fig. 4). ${ }^{6)}$ 수술 후 회복 척도는 총 15 개의 질문으로 구성되며, 신체 건강 상태, 피 로도, 일할 수 있는 능력, 활동력, 기대치의 다섯 개의 개념 을 환자 스스로 평가하는 방법으로 각각의 항목에 대하여 0

\begin{tabular}{|c|c|}
\hline 설문지 질문 & 세부 항목 \\
\hline $\begin{array}{l}\text { 수술을 받으신 당일(수술 후)에 가장 힘들었던 것은 무엇입니까? } \\
\text { (한 항목만 } \vee \text { 표 하시기 바랍니다) }\end{array}$ & $\begin{array}{l}\text { 전신 마취 후, 마취에서 잘 깨어나지 못하고 계속 졸리고 힘들었다. } \\
\text { 수술 부위 통증이 심했다. } \\
\text { 흉터를 보고 마음이 아팠다. } \\
\text { 목소리가 나빠졌다. } \\
\text { 수술 후 회복이 늦어 가사 혹은 직장으로의 복귀가 지연될 것 같았다. } \\
\text { 암이라는 사실 혹은 암일지 모른다는 사실이 걱정되었다. } \\
\text { 추가적인 암치료가 필요할지 모른다는 생각이 힘들었다. } \\
\text { 기타(구체적 기술) } \\
\text { 특별히 힘들었던 것이 기억나지 않는다. }\end{array}$ \\
\hline $\begin{array}{l}\text { 퇴원을 앞둔 지금 현재 가장 힘든 것은 무엇입니까? } \\
\text { (한 항목만 } \vee \text { 표 하시기 바랍니다) }\end{array}$ & $\begin{array}{l}\text { 아직도 마취에서 완전히 깨지 않아 계속 졸리고 힘들다. } \\
\text { 수술 부위 통증이 심하다. } \\
\text { 흉터를 보고 마음이 아프다. } \\
\text { 목소리가 나빠졌다. } \\
\text { 수술 후 회복이 늦어 가사 혹은 직장으로의 복귀가 지연될 것 같다. } \\
\text { 암이라는 사실 혹은 암일지 모른다는 사실이 걱정된다. } \\
\text { 추가적인 암치료가 필요할지 모른다는 생각이 힘들다. } \\
\text { 기타(구체적 기술) } \\
\text { 특별히 힘든 것은 없다. }\end{array}$ \\
\hline $\begin{array}{l}\text { 의료진의 판단에 따라 오늘 퇴원하시게 되었습니다. } \\
\text { 환자분의 몸과 마음의 상태를 고려했을 때 입원기간이 } \\
\text { 어떠했으면 좋겠다고 생각하십니까? } \\
\text { (한 항목만 } \vee \text { 표 하시기 바랍니다) }\end{array}$ & $\begin{array}{l}\text { 입원 기간이 더 짧았으면 좋겠다. } \\
\text { 입원 기간이 적당하다고 생각한다. } \\
\text { 입원 기간이 더 길었으면 좋겠다. } \\
\text { 잘 모르겠다. }\end{array}$ \\
\hline $\begin{array}{l}\text { 입원 기간이 더 길거나 짧았으면 좋겠다고 생각하시는 } \\
\text { 경우, 어느 정도의 입원 기간이 적당할 것이라고 } \\
\text { 생각하시는지 알려 주시기 바라며 그렇게 생각하시는 } \\
\text { 이유를 적어주십시오 }\end{array}$ & $\begin{array}{l}\text { 바람직하다고 생각하는 입원 기간: _ 박 _ 일 } \\
\text { 이유: }\end{array}$ \\
\hline
\end{tabular}

Fig. 2. The questionnaire inventory for postoperative evaluation at discharge day.

\begin{tabular}{|c|c|}
\hline 설문지 질문 & 세부 항목 \\
\hline $\begin{array}{l}\text { 퇴원 후 가장 힘들었던 것은 무엇입니까? } \\
\text { (한 항목만 } \vee \text { 표 하시기 바랍니다) }\end{array}$ & $\begin{array}{l}\text { 마취에서 회복되지 못한 것 같이 계속 졸리고 힘들었다. } \\
\text { 수술 부위 통증이 심했다. } \\
\text { 흥터를 보고 마음이 아팠다. } \\
\text { 목소리가 나빠졌다. } \\
\text { 수술 후 회복이 늦어 가사 혹은 직장으로의 복귀가 지연되었다. } \\
\text { 암이라는 사실 혹은 암일지 모른다는 사실이 걱정되었다. } \\
\text { 추가적인 암치료가 필요할지 모른다는 생각이 힘들었다. } \\
\text { 기타(구체적 기술) } \\
\text { 특별히 힘들었던 것이 기억나지 않는다 }\end{array}$ \\
\hline $\begin{array}{l}\text { 의료진의 판단에 따라 퇴원 후 일상생활로 복귀하시게 되었습니다. } \\
\text { 환자분의 몸과 마음의 상태를 고려했을 때 입원기간이 어떠했으면 } \\
\text { 좋겠다고 생각하십니까? (한 항목만 } \vee \text { 표 하시기 바랍니다) }\end{array}$ & $\begin{array}{l}\text { 입원 기간이 더 짧았으면 좋겠다. } \\
\text { 입원 기간이 적당했다고 생각한다. } \\
\text { 입원 기간이 더 길었으면 좋겠다. } \\
\text { 잘 모르겠다. }\end{array}$ \\
\hline $\begin{array}{l}\text { 입원 기간이 더 길거나 짧았으면 좋겠다고 생각하시는 경우, } \\
\text { 어느 정도의 입원 기간이 적당할 것이라고 생각하시는지 } \\
\text { 알려 주시기 바라며 그렇게 생각하시는 이유를 적어주십시오. }\end{array}$ & 이유: 박 일 \\
\hline $\begin{array}{l}\text { 현재 환자분의 몸은 수술 전에 비해 몇 \% 정도 회복되신 것 } \\
\text { 같다고 느끼십니까? }\end{array}$ & )\% \\
\hline $\begin{array}{l}\text { 수술 전처럼 회복하는 데 대략 몇 주 정도 소요될 것 } \\
\text { 같다고 느끼십니까? }\end{array}$ & 수술 후( \\
\hline
\end{tabular}

Fig. 3. The questionnaire inventory for postoperative evaluation at outpatient clinic. 


\begin{tabular}{|l|}
\hline 직접 느끼는 정도에 대해, 전혀 불편함이 없었던 경우 0점, \\
도저히 참을 수 없을 정도로 심각한 경우 10 점을 기준으로, \\
해당하는 점수에 표시해 주시기 바랍니다 \\
\hline 전반적인 몸 상태는 수술 전에 생각했던 것보다 괜찮다/좋지 않다. \\
정신은 명료하다/나른하다 \\
통증은 없다/통증이 심하다. \\
낮잠이 필요 없이 생활 가능하다/힘들어서 낮잠을 자야 한다. \\
활기 차다/피곤하다. \\
휴식이 더 필요하지 않다/휴식이 필요하다. \\
일상 생활이 가능하다/활동이 힘들다. \\
회복되는 데 하루 이틀이면 좋아질 것 같다/ \\
오랜 시간이 필요할 것 같다. \\
거동하는 것은 이전과 다름 없다/거동이 불편하다. \\
오늘 외부 활동에 문제가 없을 것 같다/있을 것 같다 \\
컨디션이 좋다/좋지 않다. \\
오늘 직장 일을 할 수 있을 것 같다/하기 힘들 것 같다. \\
주변의 도움이 없어도 일을 할 수 있을 같다/ \\
도움이 있어야 일을 할 수 있을 것 같다. \\
수술 전 상태와 동일하다/수술 전 상태로 돌아오지 못했다. \\
신체 운동이 가능하다/불가능하다.
\end{tabular}

Fig. 4. Modified postdischarge surgical recovery (PSR) scale. PSR scale is consisted of 15 questions involving the subjective recovery rate of the patients.

부터 10 까지 점수를 기록하도록 하여 완전한 회복은 $100 \%$, 전혀 회복되지 않았으면 $0 \%$ 으로 점수를 평가하는 방법이 다. 이 연구의 연구 방법은 서울대학교 의과대학/서울대병 원 의학연구윤리심의위원회의 승인을 받았다.

SPSS 16.0K (SPSS Inc., Chicago, IL, USA)를 이용하 여 통계적 분석을 시행하였다. 정규성 검정(Shapiro-Wilk) 으로 정규성과 비정규성 분포를 평가하여 연속형 변수들에 대해서는 T test, Wilcoxon test를 시행하고, 범주형 변수들 은 Fischer의 직접 확률 계산법(Fischer's exact test), 카 이제곱 검정을 시행하였다. 통계학적 유의성을 $p$ 값( $p$-value) 0.05 의 수준에서 평가하였으며, 통계 처리는 서울대학교 의 과대학 의학연구협력센터의 자문을 받았다.

\section{결 과}

\section{수술 전 설문 결과}

수술 전 갑상선 질환과 치료 과정 등에 대한 인식도에 대 한 질문에 어느 정도 알고 있다고 응답한 환자수가 30 명 (39.0\%)으로 가장 많았고, 조금 알고 있다고 응답한 수는 20 명 $(26.0 \%)$ 으로 2번째로 많았다(Fig. 5). 갑상선 질환에 대한 정보를 수집한 방법으로는 인터넷 검색이 33명(42.9\%), 주변 사람들에게서 획득한 환자가 19명(24.7\%), 병원 진 료 시간 중에 받은 교육이 17 명 $(22.1 \%)$ 으로 주를 이루었 다(Fig. 6). 수술 전 가장 걱정하고 있는 사항은 수술 및 수

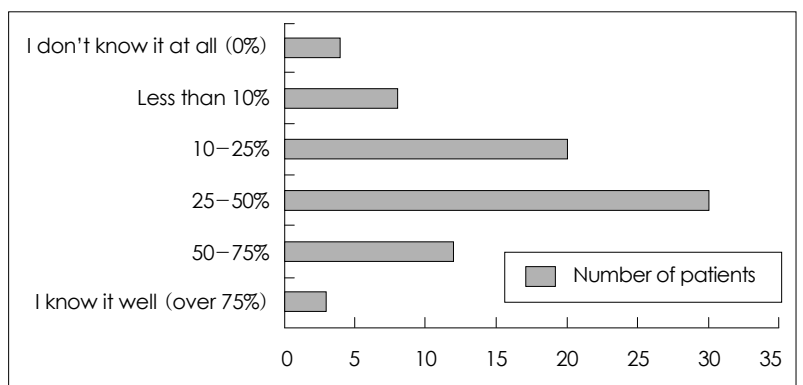

Fig. 5. Patient's description on the amount of their knowledge or understanding in the thyroid disease that they have or might have.

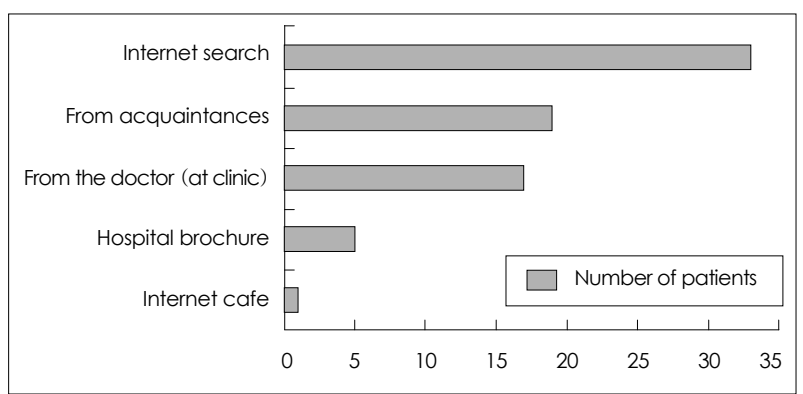

Fig. 6. How to get the knowledge of the thyroid disease?

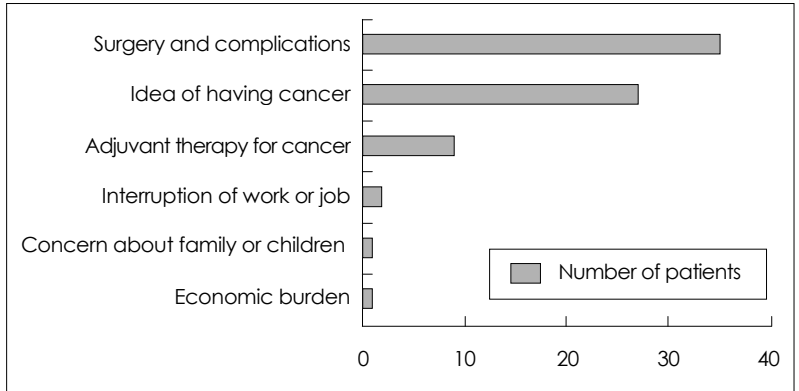

Fig. 7. The most important cause of worry before the operation on the thyroid disease.

술 합병증에 대한 걱정이 35 명 $(45.5 \%)$, 암에 대한 걱정이 27명 (35.1\%)으로 주를 이루었다(Fig. 7). 수술과 관련된 가장 걱정하는 사항은 목소리 변화가 36 명 $(46.8 \%)$, 전신 마취 부작용이 14 명 (18.2\%)으로 가장 많았다(Fig. 8). 수 술 받기 전 환자가 희망하는 입원 기간은 전적으로 병원에 서 알아서 해 줄 것으로 기대하는 환자가 49 명 $(63.7 \%)$, 가 능하면 빨리 퇴원을 원한다가 17 명(22.1\%), 가능한 오래 입원하길 희망한다가 6 명 $(7.8 \%)$, 잘 모르겠다고 응답한 환자가 5 명 $(6.5 \%)$ 이었다.

\section{수술 후 퇴원 시 설문 결과}

수술 당일 수술 후 가장 힘들었던 점은 수술 부위 통증이 31명 (40.3\%), 전신 마취와 관련된 졸리고 깨어나지 못하 는 증상이 22명 (28.6\%)으로 주를 이루었다(Fig. 9). 퇴원 


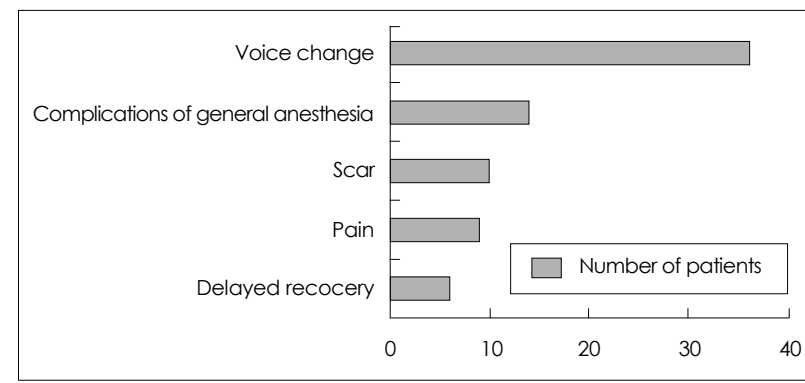

Fig. 8. The most important cause of worry related to the thyroid surgery itself, prior to the operation.

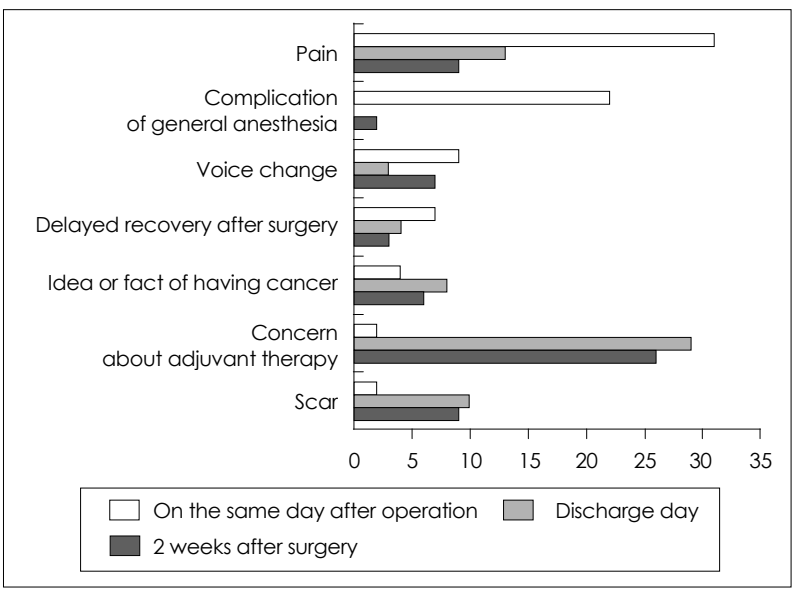

Fig. 9. Changes in the patients' cause of worries on the same day after operation, the discharge day, and at 2 weeks after the surgery (at outpatient clinic).

당일 가장 힘든 점은 수술 당일과 같은 질문 항목에 대해, 추가적인 암 치료에 대한 걱정이 29명 (37.7\%), 수술 부위 통증이 13명(16.9\%)으로 가장 많았다(Fig. 9). 퇴원 당일, 입원 기간에 대한 환자의 생각은 적당하다는 응답이 35 명 $(45.5 \%)$, 더 길었으면 좋겠다가 35 명 $(45.5 \%)$, 더 짧기 원한다는 1 명 $(1.3 \%)$, 잘 모르겠다는 6 명 $(7.8 \%)$ 으로 전체 환자들 중 입원 기간이 적당하다고 답한 환자들의 비율(만 족도)은 $45.5 \%$ 였다. 입원 기간이 더 길기를 희망한다고 응 답한 이유 중 수술 후 통증이 12 명, 상처 치료 및 봉합사 제거까지 입원을 원한다는 6 명, 불안하다는 4 명, 더 긴 휴 식을 원한다는 2 명, 퇴원 시 가사일을 해야 하기 때문이다 는 2 명, 전신상태가 안 좋다는 1 명이었다.

\section{퇴원 후 외래 설문 조사 결과}

퇴원 후(수술 후 2 주 동안) 가장 힘든 점은 추가적인 치료 에 대한 걱정이 26 명 $(33.8 \%)$ 으로 가장 많았고, 수술 부위 통증은 9명(11.7\%), 흥터 걱정은 9명(11.7\%)이었다(Fig. 9). 수술 2 주 후 외래에서 입원 기간에 대한 생각은 적당하 였다가 40 명으로 $51.9 \%$ 의 만족도를 보였고, 더 길었으면
좋겠다는 응답이 35 명 $(45.5 \%)$, 모르겠다가 2명 (2.6\%)이 었다. 입원 기간이 더 길었으면 좋겠다는 이유로는 충분한 휴식이 필요하다는 환자는 4 명, 불안하다는 3 명, 상처 관리 를 더 오래 희망한다가 3 명이었다. 수술 전에 비해서 어느 정도 회복되었는지 \%로 답하는 질문에 평균 $75.4 \%$ (표준편 차 15.4)로 대답하여, PSR scale과 환자가 기술하는 전반 적인 회복 척도는 다소 차이가 있었다(Paired T test, $p=$ 0.005). 수술 전처럼 회복되는 데 예상되는 시간을 묻는 질 문에는 수술 후 평균 4.6 주(표준편차 2.8 ) 가 걸릴 것으로 응답하였다. 퇴원 당일의 수술 후 회복 척도는 평균 $62.4 \%$ (표준편차 20.4), 2주 후에는 평균 $69.5 \%$ (표준편차 18.4) 로 시간이 지남에 따라 유의하게 차이를 보이면서 회복되었 다(Paired T test, $p=0.009$ ).

외래에서 조사한 설문이 조직 검사 결과가 악성으로 판명 된 환자군과 양성인 환자군 간의 차이가 있는지 분석하였다. 객관적인 PSR scale, 적당하고 생각하는 입원일 수, 주관적 으로 느끼는 회복 비율 $(\%)$, 수술 전처럼 회복되는 데 예상 되는 시간(주)은 두 군 간의 통계적으로 유의한 차이가 없 었다(Mann-Whitney test, 각각의 $p=0.274,0.632,0.802$, 0.671). 외래에서 조사한 입원 기간에 대한 만족도도 두 군 간의 차이는 없었다(Fisher's exact test, $p=0.731$ ).

\section{갑상선 질환에 대한 인식 분석}

갑상선 질환에 대한 이해 정도와 회복과의 관계를 파악 하기 위해 질환 이해 정도를 기준으로 질병에 대하여 전혀 모르거나 조금 알고 있는 저이해도 환자군과, 어느 정도 알 거나 잘 아는 고이해도 환자군으로 양분하여 비교 분석을 시행하였다(Table 1). 저이해도 환자군은 32 명, 고이해도 환자군은 45 명으로 분류되었다. 퇴원 당일 시행한 수술 후 회복 척도는 저이해도 환자군이 평균 $55.3 \%$ (표준편차 22.9) 로 고이해도 환자군의 평균 $67.4 \%$ (표준편차 17.1) 보다 통 계적으로 유의하게 낮았다(T test, $p=0.010)$. 외래에서 시 행한 수술 후 회복 척도는 저이해도 환자군은 평균 $64.3 \%$ (표준편차 20.2)로 고이해도 환자군의 평균 $73.3 \%$ (표준 편차 16.3) 보다 낮은 경향을 보였으나, 통계적으로 유의하 지는 않았다(Wilcoxon test, $p=0.055$ ). 고이해도 환자군 은 퇴원 시 원하는 입원 기간이 평균 4.8 일(표준편차 0.9 ) 로 저이해도 환자군의 평균인 5.4 일(표준편차 1.3 일) 보다 통계적으로 유의하게 짧았다(Wilcoxon test, $p<0.001$ ). 외 래에서는 고이해도 환자군은 원하는 입원 기간이 평균 4.5 일(표준편차 0.9)으로 저이해도 환자군의 평균인 5.1일(표 준편차 1.3)보다 짧은 경향을 보였으나 통계적으로 유의하 지는 않았다(Wilcoxon test, $p=0.064$ ). 나이를 40세 미 
Table 1. Comparison of parameters according to cognition

\begin{tabular}{|c|c|c|c|c|c|}
\hline \multirow{2}{*}{ Parameters } & \multicolumn{2}{|c|}{ Lower understanding group } & \multicolumn{2}{|c|}{ Higher understanding group } & \multirow{2}{*}{ p value } \\
\hline & Average & SD & Average & SD & \\
\hline Age & 48.94 & 11.39 & 48.42 & 10.59 & 0.839 \\
\hline PSR scale (at discharge day) & $55.3 \%$ & $22.9 \%$ & $67.4 \%$ & $17.1 \%$ & 0.010 \\
\hline PSR scale (OPD 2 weeks after surgery) & $64.3 \%$ & $20.2 \%$ & $73.3 \%$ & $16.3 \%$ & 0.055 \\
\hline Patient's wish for hospitalization at discharge day* & 5.4 & 1.3 & 4.8 & 0.9 & $<0.001$ \\
\hline Patient's wish for hospitalization at OPD 2 weeks after surgery* & 5.1 & 1.3 & 4.5 & 0.9 & 0.063 \\
\hline Actual hospitalization* & 4.1 & .8 & 4.4 & 1.2 & 0.439 \\
\hline
\end{tabular}

*days. PSR: postdischarge surgical recovery, OPD: outpatient department, SD: standard deviation

만, 40 60세, 60세 이상으로 분석하였을 때 나이에 따른 이해도의 차이는 없었다(Pearson's Chi-square test, $p=$ 0.319). 성별과 학력에 따른 이해도의 차이는 없었다(Pearson's Chi-square test, $p=0.558$, Fischer's exact test, $p=0.289$ ). 실제 입원 기간도 저이해도 환자군은 4.1일, 고 이해도 환자군은 4.4 일으로 통계적으로 유의한 차이가 없 었다(Wilcoxon test, $p=0.439$ ).

\section{입원 기간에 대한 환자 만족도의 비교}

외래에서 답한 적당한 입원 기간은 평균 4.8일(표준편차 1.2 )로 퇴원 시 조사한 평균 5.1일(표준편차 1.1) 과 실제 입 원일수인 4.3일(표준편차 1.0) 과도 통계적인 차이는 없었 다(Paired T test, $p=0.141, p=0.084$ ). 사십 세 미만, 40 60세, 60세 이상으로 나이에 따라 분석하였을 때 퇴원 시 나 외래에서 조사한 입원 기간에 대한 만족도는 차이가 없 었다(Pearson's Chi-square test, $p=0.417, p=0.441$ ). 성별에 따른 입원 기간 만족도는 퇴원 시 남자가 $63.6 \%$ 으 로 여자의 38.1\%보다 유의하게 높았고(Pearson's Chisquare test, $p=0.043)$, 외래에서도 남자가 $72.7 \%$ 로 여자 의 $43.6 \%$ 보다 유의하게 높은 만족도를 보였다 $(p=0.021)$. 수술의 범위에 따라 분석하였을 때, 갑상선 엽절제술을 시 행받은 환자는 만족도가 $35.7 \%$ 으로 전절제술을 시행받은 환자의 $47.3 \%$ 과 유의한 차이를 보이지 않았다(Pearson's Chi-square test, $p=0.667)$. 퇴원 시 입원 기간에 대한 만 족을 보인 환자가 불만족한 환자보다 외래에서 작성한 수 술 후 회복 척도가 높았으며 $(75.1 \%$ vs. $64.9 \%, p=0.03)$, 외래에서 원하는 입원 기간이 더 짧았고(4.2일 vs. 5.0일, $p=0.02)$, 회복되는 데 환자가 예상한 시간이 더 짧았다(3.8 주 vs. 5.3주, Wilcoxon test, $p=0.04$ ).

\section{고 찰}

환자가 자신의 질병을 인식할 때 암의 진행 정도와 상관 없이 교육의 정도만이 인식과 상관 관계를 가지며, 환자들
은 병의 심각한 정도와 상관없이 주관적으로, 감정적으로 자 신의 질병을 인식한다. ${ }^{7}$ 자신의 질병에 대하여 더 많은 지 식을 갖춘 환자는 건강과 관련된 시스템을 더 잘 활용한다 고 한다. ${ }^{89}$ 또한 환자가 자신의 질병을 인식하는 방법에 따 라 환자의 삶의 질은 달라진다고 한다. ${ }^{7)}$ 이번 연구에서도 고이해도 환자군이 저이해도 환자군보다 퇴원 시나 외래에 서 더 높은 회복률을 보였고, 원하는 입원 기간도 짧았다. 본 연구에서는 갑상선 질환에 대한 환자 자신의 이해 정도 를 전혀 모르거나, 거의 모르거나, 조금 알고 있는 정도라 고 표현한 환자가 $41.6 \%$ 로, 저자들의 이번 연구는 환자들 을 대상으로 더 많은 교육이 필요하다는 것을 알 수 있었다.

오늘날 환자들은 자신의 질병의 진단과 치료에 적극적인 역할을 하고 싶어하고, 자신들이 치료의 소비자라고 생각하 며, 최대한 많은 양의 정보를 습득하기를 원한다. ${ }^{10-12)}$ 암 진단을 받은 환자는 수술을 받은 환자보다 더 많은 정보를 필요로 하고, 질병에 의해 더 많은 영향을 받으며, 정신적 으로 더 좌절한다. ${ }^{13)} 24$ 시간 동안 접근이 가능하다는 점과 인터넷 사용이 범세계적으로 증가하는 점 때문에 인터넷은 현 시점에서 환자의 교육을 위한 중요한 수단이다. ${ }^{14,15)}$ 본 연구에서도 갑상선 질환에 대한 정보는 인터넷 검색을 통한 것이 42.9\% (33명)로 가장 많았다. Yeo 등 ${ }^{16)}$ 은 Google, Ya$\mathrm{hoo}, \mathrm{MSN}$ 에서 갑상선 질환에 대한 가장 접속이 많은 50 개 의 사이트를 분석하였는데, 수술의 적응증에 대하여 설명한 사이트는 $50 \%$, 반회후두신경 손상과 쉰 목소리의 가능성 은 $42 \%$, 부갑상선 손상과 부갑상선 기능 저하증은 $42 \%$ 로 충분하지 않은 정보를 제공하고 있었고, $38 \%$ 의 사이트만이 2 년 이내로 최신화되어 있었다. 따라서 인터넷을 통한 갑상 선 질환에 대한 교육과 정보의 최신화가 필요하다.

암 환자의 수술 후 회복 과정에서 환자들의 요구와 의사 들이 생각하는 중요한 점들은 다를 수 있다. 한 연구에서는 환자가 가장 중요하다고 생각하는 점은 치료(치료 방법들, 치료의 이점과 합병증)인 반면, 의료진은 환자의 회복에 있 어서 통증 조절과 통증 이외의 다른 증상들, 합병증을 가장 중요한 점으로 평가하였고, 이는 암의 종류나 치료 정도에 
관계없이 일치함을 보였다. ${ }^{17)}$ 이번 연구에서 수술 전 환자 가 가장 걱정하는 점은 수술과 수술 합병증이 가장 많았고 (45.5\%), 암이라는 사실 $(35.1 \%)$ 이 그 다음으로 많았다. 수술과 관련하여 가장 걱정하는 점은 목소리 변화가 가장 많았고 $(46.8 \%)$, 전신 마취 부작용 $(18.2 \%)$ 이 다음으로 많 았다. 따라서 수술 전에는 수술과 수술 관련 합병증에 관련 된 교육이 필요하고, 암의 예후와 정신적인 지지가 필요하다. 갑상선 수술을 받는 환자가 치료 과정 중 가장 힘들다고 느끼는 사항은 치료가 진행됨에 따라 다르다. 수술 직후 가 장 힘든 점은 수술 부위 통증 $(40.3 \%)$, 전신 마취와 관련된 졸리고 깨어나지 못하는 증상 $(28.6 \%)$ 이 가장 많은 반면, 퇴원 당일은 추가적인 암 치료에 대한 걱정 $(37.7 \%)$, 수술 부위 통증 $(16.9 \%)$ 이 주를 이루었고, 수술한 지 2주가 지 난 외래에서는 추가적인 암 치료 $(33.8 \%)$ 가 가장 많은 응 답을 얻었다. 따라서 수술 직후에는 통증 관리와 마취 관련 합병증에 대한 교육과 처치가 필요하고, 수술한 이후는 추 가적인 암 치료에 대한 철저한 교육이 환자의 삶의 질을 높 일 수 있다. 환자들이 희망하는 입원 기간에 대한 답변은 수 술 전과 수술 후 시간이 지남에 따라 변화하는 양상을 볼 수 있었다. 퇴원 시 입원 기간을 연장하고 싶은 이유는 주 로 수술 부위 통증과 상처 관리이고, 외래에서는 휴식과 불 안감이 주를 이루었다. 따라서 입원 기간 동안 통증 관리, 상처 관리에 좀 더 힘써야 하고, 환자 교육에 있어서 수술 직후, 퇴원, 외래에서 정신적으로 지지해 주고 교육해야 할 사항이 다름을 인식해야 한다. 입원 기간에 대한 만족도는 나이에 따라 차이가 없었으나, 여자 환자가 퇴원 시나 외래 에서 더 낮은 만족도를 보였다. 따라서 환자의 성별에 따라 서도 환자 교육 및 수술 후 치료에 정신적 지지에 차이를 둘 필요가 있다.

결론적으로 갑상선 수술을 받는 환자 중 질환 및 치료에 대한 인식 정도가 높은 환자들은 자신이 느끼는 수술 후 회 복률이 높게 나타나고, 원하는 입원 일수가 감소하였다. 갑상 선 질환에 대한 교육 기회를 제공하고, 수술 전후의 불안과 불편에 대해 보조해 주면, 수술 입원 기간을 줄이면서 입원 동안의 만족도를 높이고, 빠른 회복에도 도움이 될 것이다.

\section{Acknowledgments}

This work was supported by the Research Grant funded by Seoul National University Hospital (04-2008-0050).

\section{REFERENCES}

1) Dagan T, Bedrin L, Horowitz Z, Chaushu G, Wolf M, Kronenberg J, et al. Quality of life of well-differentiated thyroid carcinoma patients. J Laryngol Otol 2004;118 (7) :537-42.

2) Korea Central Cancer Registry', Ministry for Health', Welfare and Family Affairs of Korea. Cancer Statistics 2006-2007. 2009.12.21. Available from: URL: http://www.cancer.go.kr

3) Hoftijzer HC, Heemstra KA, Corssmit EP, van der Klaauw AA, Romijn JA, Smit JW. Quality of life in cured patients with differentiated thyroid carcinoma. J Clin Endocrinol Metab 2008;93 (1):200-3.

4) Ganz PA. Quality of life and the patient with cancer. Individual and policy implications. Cancer 1994;74 (4 Suppl):1445-52.

5) Almeida J, Vartanian JG, Kowalski LP. Clinical predictors of quality of life in patients with initial differentiated thyroid cancers. Arch Otolaryngol Head Neck Surg 2009;135 (4) :342-46.

6) Kleinbeck SV. Self-reported at-home postoperative recovery. Res Nurs Health 2000;23 (6):461-72.

7) Hirsch D, Ginat M, Levy S, Benbassat C, Weinstein R, Tsvetov G, et al. Illness perception in patients with differentiated epithelial cell thyroid cancer. Thyroid 2009;19(5):459-65.

8) Stalmeier PF, Roosmalen MS, Verhoef LC, Hoekstra-Weebers JE, Oosterwijk JC, Moog U, et al. The decision evaluation scales. Patient Educ Couns 2005;57 (3):286-93.

9) Légaré F, O'Connor AM, Graham ID, Wells GA, Jacobsen MJ, Elmslie $\mathrm{T}$, et al. The effect of decision aids on the agreement between women's and physicians' decisional conflict about hormone replacement therapy. Patient Educ Couns 2003;50 (2) :211-21.

10) Wirtz V, Cribb A, Barber N. Patient-doctor decision-making about treatment within the consultation--a critical analysis of models. Soc Sci Med 2006;62 (1):116-24.

11) McRoy SW, Liu-Perez A, Ali SS. Interactive computerized health care education. J Am Med Inform Assoc 1998;5 (4) :347-56.

12) Ruland CM, Bakken S. Developing, implementing, and evaluating decision support systems for shared decision making in patient care: a conceptual model and case illustration. J Biomed Inform 2002;35 (56) :313-21.

13) Chen SC, Lai YH, Liao CT, Chang JT, Lin CC. Unmet information needs and preferences in newly diagnosed and surgically treated oral cavity cancer patients. Oral Oncol 2009;45(11):946-52.

14) Berland GK, Elliott MN, Morales LS, Algazy JI, Kravitz RL, Broder MS, et al. Health information on the Internet: accessibility, quality, and readability in English and Spanish. JAMA 2001;285(20):2612-21.

15) Ford $P$. Is the Internet changing the relationship between consumers and practitioners? J Healthc Qual 2000;22(5):41-3.

16) Yeo H, Roman S, Air M, Maser C, Trapasso T, Kinder B, et al. Filling a void: thyroid cancer surgery information on the internet. World $\mathrm{J}$ Surg 2007;31(6):1185-91; discuscion 1192-3.

17) Snyder CF, Dy SM, Hendricks DE, Brahmer JR, Carducci MA, Wolff $\mathrm{AC}$, et al. Asking the right questions: investigating needs assessments and health-related quality-of-life questionnaires for use in oncology clinical practice. Support Care Cancer 2007;15(9):1075-85. 